\title{
Analisis Kemampuan Koneksi Matematis Siswa Menggunakan Pendekatan Pembelajaran CTL dan RME
}

\author{
Eneng Diana Putri Latipah, Ekasatya Aldila Afriansyah \\ Program Studi Pendidikan Matematika, Institut Pendidikan Indonesia, Garut, Indonesia \\ enengdiana379@gmail.com, ekasatyafriansyah@institutpendidikan.ac.id
}

\begin{abstract}
Abstrak. Penelitian ini dilatarbelakangi dari pentingnya kemampuan koneksi matematis terutama di tingkat sekolah menengah pertama. Tujuan penelitian ini adalah untuk mengetahui kemampuan koneksi matematis siswa yang mendapat pendekatan pembelajaran CTL dan pendekatan pembelajaran RME. Serta respon siswa terhadap kedua pendekatan tersebut. Metode penelitian yang digunakan adalah metode kuasi eksperimen dengan desain The Static group pretest-posttest design. Populasi penelitian ini yaitu siswa SMP 2 Cilawu. Sedangkan sampel penelitiannya adalah siswa kelas VII yaitu kelas VII-D sebagai kelas eksperimen 1 sebanyak 31 siswa, dan kelas VII-A sebagai kelas eksperimen 2 sebanyak 30 siswa. Dari hasil penelitian menunjukkan bahwa kemampuan koneksi matematis siswa yang mendapat pendekatan CTL dengan siswa yang mendapat pendekatan pembelajaran RME sama baiknya. Kualitas peningkatan kedua pendekatan tersebut berinterpretasi sedang, dan sebagian besar siswa memiliki interpretasi sikap baik terhadap pembelajaran Matematika dengan menggunakan pendekatan CTL dan sebagian besar siswa memiliki interpretasi sikap cukup baik terhadap pembelajaran Matematika dengan menggunakan pendekatan RME.
\end{abstract}

Kata kunci: Pendekatan CTL, Pendekatan RME, Kemampuan Koneksi Matematis, The Static Group Pretest-Posttest Design

\begin{abstract}
The analysis of students' mathematical connection skills using CTL and RME approaches) This research has background with the important of the mathematics connection ability especially in junior high school. The aim of this research is to know the mathematics connection ability that has got approach CTL and RME. As well as response the students with two learn approaches. The method of this research used Quasi-experimental method with the static group pretest-posttest design. Population of this research is the students of SMPN 2 CILAWU. Whereas the sample of the research is the students class of VII-D as experiment class 1 as many as 31 students and Students class of VIIA as experiment class 2 as many as 30 students. As the result from this research, showed that the students mathematics connection ability who got CTL same good result with the students who got RME. The two approach enhancement has Intermediate interpretation quality, and a lot of the students have a god attitude interpretation with mathematic learning with CTL approach and a lot of the students have well enough attitude interpretation with mathematic learning.
\end{abstract}

Keywords: CTL Approach, RME Approach, Mathematics Connection Ability, The Static Group Pretest-Posttest Design

\section{Pendahuluan}

Proses pembelajaran pada pendidikan di Indonesia sebagian besar masih berorientasi pada guru. Sebagaimana menurut Budiarto [1] bahwa proses pembelajaran masih didominasi datang dari guru, sementara siswa sebagai obyek untuk menerima informasi yang dianggap penting dari materi-materi yang disampaikan oleh guru serta tidak berani mengeluarkan ide-ide pada saat pembelajaran berlangsung. Hal tersebut mengakibatkan lemahnya proses pembelajaran di dalam kelas, yang mengakibatkan siswa kurang berperan aktif. 
Belajar merupakan kegiatan sehari-hari bagi siswa sekolah. Di sekolah siswa banyak mempelajari berbagai mata pelajaran salah satunya adalah mata pelajaran Matematika. Matematika adalah suatu ilmu yang berhubungan dengan orang banyak yang berperan penting terhadap perkembangan ilmu pengetahuan dan teknologi.

Matematika merupakan ilmu yang memiliki keterkaitan antar topik-topiknya seperti yang diungkapkan Hirdjan [2] yang menyatakan bahwa matematika tidak diajarkan secara terpisah antar topik. Masing-masing topik bisa dilibatkan atau terlibat dengan topik lainnya. Oleh karena itu, pemahaman siswa pada suatu topik akan membantu untuk memahami topik yang lain, tetapi hal ini bisa terjadi jika siswa mampu mengkoneksikan topik-topik tersebut. Dan juga, Matematika memiliki keterkaitan dengan ilmu lainnya. Maka dari itu siswa dituntut untuk bisa menghubungkan antar topik yang satu dengan topik lainnya. Kemampuan matematika dalam menghubungkan topik yang satu dengan yang lainnya adalah kemampuan koneksi matematis, namun pada kenyataannya dilapangan, kemampuan koneksi matematis siswa masih rendah.

Ada beberapa penyebab rendahnya kemampuan koneksi matematis siswa diantaranya adalah pembelajarannya berpusat pada guru, dan soal yang diberikan cenderung tidak bervariatif sehingga pada saat siswa diberikan soal soal yang berhubungan dengan kehidupan sehari-hari, siswa tidak bisa menyelesaikan soal tersebut. Sejalan dengan yang diungkapkan oleh Putri dan Santosa [3] yaitu Penyebab rendahnya kemampuan koneksi matematis siswa dapat dilihat dari proses pembelajaran yang dilakukan dikelas yang cenderung pembelajaran berpusat pada guru (teacher oriented), dimana siswa cenderung pasif dalam menerima pelajaran, kurangnya rasa tanggung jawab dalam diri siswa sehingga mengakibatkan siswa malas dan enggan dalam memecahkan masalah dan menyelesaikan soal. Soal-soal yang diberikan guru masih sebatas hanya soal-soal perhitungan rutin yang kurang memberikan kesempatan kepada siswa untuk menganalisis permasalahan hidup sehari-hari. Kecenderungan pembelajaran Matematika yang terjadi di kelas hanya sekedar mencatat, membaca, dan menulis tanpa mengamati permasalahan yang ada dilingkungan sekitarnya sehingga tidak terlatih untuk menyelesaikan permasalahan hidup sehari-hari yang berhubungan dengan konsep Matematika.

Dengan adanya kemampuan koneksi Matematika memungkinkan siswa mampu menghubungkan keterkaitan antara konsep-konsep yang diperolehnya secara terpisah untuk digunakan atau diaplikasikan pada konteks yang nyata sehingga dapat memberi makna yang lebih baik untuk diri siswa yang diharapkan dapat membangkitkan minat belajar siswa terhadap matematika. Hal ini karena siswa bukan hanya sekedar mengetahui namun juga dapat memaknai dan merasakan langsung manfaat dari penguasaan konsep Matematika dalam kehidupan sehari-hari.

Berdasarkan uraian di atas, perlu dilakukan usaha dalam pembelajaran Matematika disekolah terutama untuk meningkatkan kemampuan koneksi matematis siswa. Usaha ini memerlukan pendekatan pembelajaran matematika yang dapat menarik siswa terhadap mata pelajaran Matematika, dan dapat memberikan gambaran tentang apa yang dipelajari dan dapat dikoneksikan dengan kehidupan nyata. Oleh karena itu, pendekatan yang dinilai mampu meningkatkan kemampuan koneksi matematis siswa yaitu dengan menggunakan pendekatan Contextual Teaching and Learning (CTL) dan Realistic Mathematics Education (RME).

Alwasilah [4] berpendapat bahwa pendekatan CTL merupakan konsep belajar yang dapat membantu guru mengaitkan antara materi yang diajarkannya dengan situasi dunia nyata siswa dan mendorong siswa membuat hubungan antara pengetahuan yang dimilikinya dengan penerapannya dalam kehidupan mereka sebagai anggota keluarga dan masyarakat.

Beberapa penelitian relevan telah menerapkan pendekatan pembelajaran CTL dan terbukti dapat meningkatkan kemampuan matematis siswa, yaitu: kemampuan koneksi matematis [5, 6]; dan kemampuan penalaran statistis [7].

Inovasi pembelajaran lain yang dipandang dapat mengatasi permasalahan pembelajaran di sekolah adalah penerapan pendekatan RME. RME memberikan kesempatan pada siswa untuk lebih aktif dalam pembelajaran, dikarenakan pembelajaran yang dilakukan lebih terpusat pada siswa [8]. Pendidikan Matematika Realistik adalah suatu pendekatan pembelajaran matematika yang harus 
selalu menggunakan masalah sehari-hari. Pendekatan ini didasarkan pada anggapan Hans Freudenthal [9] yang menyatakan bahwa Mathematics is a human activity and must be connected to reality. Konsep Hans Freudenthal ini tercermin dalam banyaknya kesempatan yang diberikan oleh guru kepada siswa mereka untuk membangun pemahaman mereka sendiri [10]. Menurut pandangannya, Matematika harus terkait dengan kenyataan, dekat dengan pengalaman atau dunia anak dan relevan dengan kehidupan nyata sehari hari bagi masyarakat. Menurut Freudhental [11] bahwa RME menggabungkan pandangan tentang apa matematika, bagaimana siswa belajar matematika dan bagaimana matematika harus diajarkan.

Menurut Afriansyah [12], pembelajaran RME merupakan sebuah teori pembelajaran yang dikembangkan di Belanda sejak tahun 1970-an oleh Hans Freudhental menekankan pada membangun konsep matematika yang bermakna. Dalam hal ini guru hanya sebagai fasilitator dan motivator interaksi antar siswa. Pendekatan RME sangat membantu siswa untuk berpikir dari hal yang abstrak menjadi hal yang konkrit atau nyata. Akan tetapi, realistic dalam RME tidak diharuskan nyata/ada, tetapi juga boleh hanya dapat dibayangkan [13]. Contoh penelitian pembelajaran menggunakan RME yang telah dilakukan sebelumnya dan hasilnya positif adalah pada penelitian Ulfah dan Eka di tahun 2017, mereka berdua membandingkan pendekatan RME dengan Open-Ended, dan hasilnya adalah RME lebih baik daripada Open-Ended [14].

Berikut ini disajikan beberapa penelitian relevan telah menerapkan pendekatan pembelajaran RME, yaitu: kemampuan berpikir logis [15], hasil belajar [16], kemampuan berpikir kreatif matematis [17], dan kemampuan komunikasi matematis [18, 19].

Diantara pendekatan pembelajaran CTL dan pendekatan pembelajaran RME terdapat perbedaan, CTL dapat diterapkan dalam berbagai bidang studi. Sedangkan RME lebih banyak diterapkan pada bidang studi Matematika dan sepengetahuan peneliti tidak banyak yang menerapkan di bidang studi lain. Asumsi lainnya yaitu pada awal pembelajaran CTL diberikan sedikit materi sedangkan RME tidak diberikan sedikitpun materi, sehingga peneliti berasumsi bahwa CTL lebih baik daripada RME. Akan tetapi, asumsi ini perlu di uji kebenarannya, karena sejauh ini belum ada penelitian relevan yang mengkaji tentang ini.

Berdasarkan uraian pada latar belakang masalah di atas, rumusan masalah dalam penelitian ini adalah sebagai berikut:

(1) Bagaimana peningkatan kemampuan koneksi matematis siswa yang mendapat pendekatan CTL?

(2) Bagaimana peningkatan kemampuan koneksi matematis siswa yang mendapat pendekatan RME?

(3) Bagaimana sikap siswa terhadap pendekatan CTL?

(4) Bagaimana sikap siswa terhadap pendekatan RME?

Koneksi merupakan suatu kemampuan dalam menghubungkan salah satu ilmu dengan kehidupan sehari-hari, koneksi merupakan kemampuan yang sangat penting untuk dikuasai oleh siswa, sebab kemampuan mengkoneksi atau menghubungkan ini akan memudahkan siswa dalam menyelesaikan soal yang berkaitan dengan kehidupan sehari-hari.

Adapun indikator kemampuan koneksi matematis menurut Herdiana \& Sumarmo [20] adalah sebagai berikut:

(1) Memahami representasi ekivalen suatu konsep, proses, atau prosedur matematik,

(2) Mencari hubungan berbagai representasi konsep, proses, atau prosedur matematik

(3) Memahami hubungan antartopik Matematika.

(4) Menerapkan Matematika dalam bidang lain atau dalam kehidupan sehari-hari.

(5) Mencari hubungan satu prosedur dengan prosedur lain dalam representasi yang ekuivalen.

(6) Menerapkan hubungan antar topik Matematika dan antara topik matematika dengan topik disiplin ilmu lainnya. 
Johnson [21] mengungkapkan bahwa pendekatan CTL adalah keterkaitan setiap materi atau topik pembelajaran dengan kehidupan nyata. Untuk mengaitkannya bisa dilakukan berbagai cara, selain karena memang materi yang dipelajari secara langsung terkait dengan kondisi faktual, juga bisa disiasati dengan pemberian ilustrasi atau contoh, sumber belajar, media, dan lain sebagainya, yang memang baik secara langsung maupun tidak diupayakan terkait atau ada hubungan dengan pengalaman hidup nyata.

Menurut Rusman [21] langkah-langkah CTL sebagai berikut:

(1) Mengembangkan pemikiran siswa untuk melakukan kegiatan belajar lebih bermakna, apakah dengan cara bekerja sendiri, menemukan sendiri, dan mengonstruksi sendiri pengetahuan dan keterampilan baru yang akan dimilikinya.

(2) Melaksanakan sejauh mungkin kegiatan inquiry untuk semua topik yang diajarkan.

(3) Mengembangkan sifat ingin tahu siswa melalui memunculkan pertanyaan-pertanyaan.

(4) Menciptakan masyarakat belajar,seperti melalui kegiatan kelompok, berdiskusi, tanya jawab, dan lain sebagainya.

(5) Menghadirkan model sebagai contoh pembelajaran, bisa melalui ilustrasi, model, bahkan media yang sebenarnya.

(6) Membiasakan anak untuk melakukan refleksi dari setiap kegiatan pembelajaran yang telah dilakukan.

(7) Melakukan penilaian secara objektif, yaitu menilai kemampuan yang sebenarnya pada setiap siswa.

Menurut Wijaya [9], banyak pihak yang menganggap bahwa pendekatan RME adalah suatu pendekatan dalam pembelajaran matematika yang harus menggunakan masalah sehari-hari. Penggunaan kata Realistic sebenarnya berasal dari bahasa Belanda Zinch Realistic yang berarti untuk dibayangkan atau To Imagine. Penggunaan kata realistik tersebut tidak sekedar menunjukan adanya koneksi dunia nyata tetapi lebih mengacu pada fokus pendidikan matematika realistik dalam menempatkan penekanan penggunaan suatu situasi yang bisa dibayangkan oleh siswa.

Pendekatan RME secara garis besar memiliki lima karakteristik. Menurut Treffers dan Van den Heuvel-Panhuizen [9] adalah sebagai berikut:

(1) Penggunaan konteks

(2) Penggunaan model (matematisasi)

(3) Pemanfaatan hasil konstruksi siswa

(4) Interaktivitas

(5) Keterkaitan (intertwinning)

\section{Metode}

Dalam penelitian ini, metode yang digunakan oleh peneliti adalah metode kuasi eksperimen (quasi eksperiment) dengan sampel sebanyak dua kelompok. Kelompok yang diberikan perlakuan pendekatan pembelajaran Contextual Teaching and Learning (CTL) sebagai kelas eksperimen 1 dan kelompok yang diberikan perlakuan pendekatan pembelajaran Realistic Mathematics Education (RME) sebagai kelas eksperimen 2.

Populasi dalam penelitian ini adalah seluruh siswa seluruh siswa SMP Negeri 2 Cilawu kelas VII, tahun ajaran 2016-2017. Selanjutnya sampel diambil dua kelas yang dipilih oleh guru mata pelajaran, yaitu kelas VII-D sebagai kelompok CTL dengan banyaknya siswa 31 orang dan kelas VII-A sebagai kelompok RME dengan banyak siswa 30 orang.

Penelitian ini dilaksanakan pada semester genap tahun akademik 2016/2017 pada tanggal 22 Maret sampai dengan 15 Mei 2017. Tempat pelaksanaan penelitian di SMP Negeri 2 Cilawu yang beralamat di jalan raya Bayongbong KM 5, Desa Mangkurayat, Kecamatan Cilawu, Kabupaten Garut. 
Berdasarkan uraian di atas, maka desain penelitian ini menurut Fraenkel dan Wallen [22] yang dinamakan the static group pretest-posttest design desain penelitiannya adalah sebagai berikut:

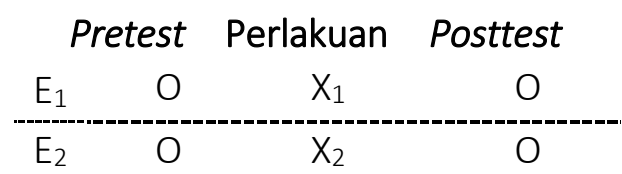

Keterangan:

$\mathrm{E}_{1}=$ Kelas eksperimen 1

$\mathrm{E}_{2}=$ Kelas eksperimen 2

$\mathrm{O}=$ Pretest dan Posttest

$\mathrm{X}_{1}=$ Pembelajaran menggunakan CTL

$\mathrm{X}_{2}=$ Pembelajaran menggunakan RME

Analisis data dilakukan untuk memberikan gambaran terhadap data yang telah dikumpulkan dari hasil penelitian. Analisis data dilakukan untuk memberikan gambaran terhadap data yang telah dikumpulkan dari hasil penelitian. Hal ini dimaksudkan untuk mencari kesimpulan dan menguji hipotesis. Data yang dianalisis diperoleh dari hasil pretest, posttest, dan angket. Pretest dilakukan pada kedua kelas eksperimen untuk menganalisis kemampuan awal siswa sebelum diberikan pembelajaran. Kemudian, kedua kelas diberi posttest. Analisis data angket berkenaan dengan pengukuran non-tes. Lalu pemberian angket untuk mengukur respon siswa terhadap model pembelajaran yang diberikan.

\section{Hasil dan Pembahasan}

Dalam penelitian yang dilakukan dari 63 siswa yang menjadi subjek penelitian, hanya 61 siswa yang datanya terkumpul secara lengkap dan sesuai dengan kebutuhan penelitian. 2 dari 63 siswa tersebut data-datanya tidak diikutsertakan dalam penelitian ini, dikarenakan data siswa yang bersangkutan tidak lengkap yaitu tidak mengikuti pretest ataupun posttest.

\subsection{Analisis Data Tes Awal (Pretest)}

Adapun hipotesis yang dirumuskan dengan taraf signifikan sebesar 5\% untuk mengetahui perbedaan rerata pretest adalah sebagai berikut:

Ho: Tidak terdapat perbedaan kemampuan awal yang signifikan antara siswa yang mendapat pendekatan CTL dengan yang mendapat pendekatan RME.

Ha: Terdapat perbedaan kemampuan awal yang signifikan antara siswa yang mendapat pendekatan CTL dengan yang mendapat pendekatan RME.

Tabel 1. Hasil Data Tes Kemampuan Awal.

\begin{tabular}{|ccc|}
\hline Keterangan & Kelas CTL & Kelas RME \\
\hline $\boldsymbol{N}$ & $\mathbf{3 1}$ & 30 \\
\hline $\boldsymbol{U}$ & 793 & 1098 \\
\hline $\boldsymbol{\mu}_{u}$ & 633 \\
\hline $\boldsymbol{T} \boldsymbol{T}$ & 465 \\
\hline $\boldsymbol{\delta}_{U}$ & 155 \\
\hline $\boldsymbol{Z}_{\text {hitung }}$ & 60,03 \\
\hline $\boldsymbol{Z}_{\text {tabel }}$ & 2,43 \\
\hline Kesimpulan & \multicolumn{2}{c|}{1,96} \\
\hline
\end{tabular}


Berdasarkan tabel 1, terlihat nilai $Z_{\text {hitunn }}$ berada pada daerah penolakan Ho. Sehingga dapat disimpulkan bahwa terdapat perbedaan kemampuan awal yang signifikan antara kelas CTL dan kelas RME.

\subsection{Analisis Data Tes Akhir (Posttest)}

Tabel 2. Hasil Data Tes Kemampuan Akhir.

\begin{tabular}{ccc}
\hline Kelas & N & Rata-rata \\
\hline CTL & 31 & 0,558 \\
\hline RME & 30 & 0,431 \\
\hline
\end{tabular}

Berdasarkan tabel 2, dapat dilihat bahwa rata-rata nilai posttest dari tiap pendekatan pembelajaran.

\subsection{Deskripsi Hasil Gain Ternormalisasi}

Dari hasil perhitungan gain ternormalisasi didapat hasil dalam bentuk persentase, sehingga memudahkan untuk mengklasifikasikan setiap siswa dalam kategori yang didapat. Hasil yang diperoleh sebagai berikut:

Tabel 3. Persentasi Kualitas Peningkatan Kemampuan Koneksi Matematis Kelas CTL Setelah Diberikan Pembelajaran.

\begin{tabular}{|cccc|}
\hline No & Kategori & Banyak siswa & Persen \\
\hline 1 & Tinggi & 12 & $39 \%$ \\
\hline 2 & Sedang & 11 & $35 \%$ \\
\hline 3 & Rendah & 8 & $26 \%$ \\
\hline & Jumlah & $\mathbf{3 1}$ & $\mathbf{1 0 0 \%}$ \\
\hline
\end{tabular}

Berdasarkan tabel 3, dapat disimpulkan bahwa untuk kelas CTL mengalamai kualitas peningkatan kemampuan koneksi matematis dengan kategori sedang diambil dari nilai rata-rata gain. Perhitungan deskripsi gain ternormalisasi pada kelas RME sama dengan perhitungan pada kelas CTL.

Tabel 4. Persentasi Kualitas Peningkatan Kemampuan Koneksi Matematis Kelas RME Setelah Diberikan Pembelajaran.

\begin{tabular}{|cccc|}
\hline No & Kategori & Banyak siswa & Persen \\
\hline 1 & Tinggi & 9 & $30 \%$ \\
\hline 2 & Sedang & 6 & $20 \%$ \\
\hline 3 & Rendah & 15 & $50 \%$ \\
\hline & Jumlah & $\mathbf{3 0}$ & $\mathbf{1 0 0 \%}$ \\
\hline
\end{tabular}

Berdasarkan tabel 4, dapat disimpulkan bahwa untuk kelas RME mengalamai kualitas peningkatan kemampuan koneksi matematis dengan kategori sedang diambil dari nilai rata-rata gain.

Dari hasil perhitungan uji gain ternormalisasi kedua kelas, diperoleh hasil sebagai berikut. 


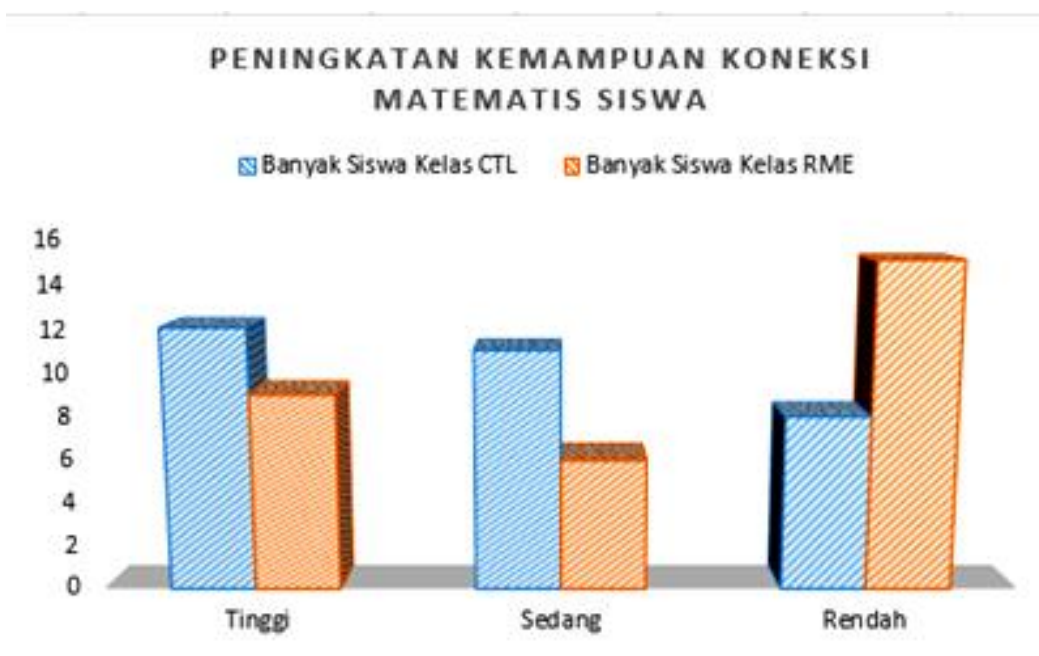

Gambar 1. Interpretasi Gain Ternormlisasi Siswa Kelas CTL dan RME.

Dari gambar 1 diperoleh bahwa peningkatan kemampuan koneksi matematis siswa pada siswa kategori tinggi dan sedang, kelas CTL lebih banyak dibandingkan kelas RME. Berbanding terbalik pada siswa kategori rendah, peningkatan kemampuan koneksi matematis siswa kelas RME lebih banyak dibandingkan kelas CTL.

\subsection{Analisis Data Sikap}

Tabel 5. Interpretasi Skala Sikap Siswa Kelas CTL Secara Umum.

\begin{tabular}{|c|c|c|c|}
\hline Aspek & Jumlah & Jumlah Seluruh & Interpretasi \\
\hline Terhadap Pelajaran Matematika & 705 & \multirow{3}{*}{1809} & \multirow{3}{*}{ Baik } \\
\hline Terhadap Pendekatan CTL & 613 & & \\
\hline $\begin{array}{l}\text { Terhadap Soal-Soal } \\
\text { Kemampuan Koneksi }\end{array}$ & 491 & & \\
\hline
\end{tabular}

Berdasarkan tabel 5, didapat bahwa interpretasi skala sikap siswa secara umum terhadap pendekatan CTL mendapat interpretasi sikap yang baik.

Tabel 6. Interpretasi Skala Sikap Siswa Kelas RME Secara Umum.

\begin{tabular}{|c|c|c|c|}
\hline Aspek & Jumlah & Jumlah Seluruh & Interpretasi \\
\hline Terhadap Pelajaran Matematika & 705 & \multirow{3}{*}{1684} & \multirow{3}{*}{ Cukup } \\
\hline Terhadap Pendekatan CTL & 666 & & \\
\hline $\begin{array}{l}\text { Terhadap Soal-Soal } \\
\text { Kemampuan Koneksi }\end{array}$ & 491 & & \\
\hline
\end{tabular}

Berdasarkan tabel 6, didapat bahwa interpretasi skala sikap siswa secara umum terhadap pendekatan RME mendapat interpretasi sikap cukup baik.

Adapun interpretasi kemampuan komunikasi matematis siswa terhadap masing-masing indikator disajikan pada tabel berikut. 
Tabel 7. Interpretasi Kemampuan Koneksi Matematis Siswa terhadap masing-masing Indikator.

\begin{tabular}{|ccccc|}
\hline \multicolumn{1}{|c}{ Keterangan } & \multicolumn{2}{c}{ CTL } & \multicolumn{2}{c}{ RME } \\
\cline { 2 - 5 } & $\begin{array}{c}\text { Jumlah } \\
\text { Skor }\end{array}$ & Interpretasi & Jumlah Skor & Interpretasi \\
\hline Indikator ke-1 & 246 & Cukup & 214 & Cukup \\
\hline Indikator ke-2 & 300 & Cukup & 295 & Cukup \\
\hline Indikator ke-3 & 159 & Cukup & 157 & Cukup \\
\hline Indikator ke-4 & 175 & Baik & 158 & Cukup \\
\hline Indikator ke-5 & 158 & Cukup & 147 & Cukup \\
\hline Indikator ke-6 & 280 & Baik & 256 & Baik \\
\hline Indikator ke-7 & 161 & Cukup & 153 & Cukup \\
\hline Indikator ke-8 & 193 & Baik & 187 & Baik \\
\hline Indikator ke-9 & 137 & Cukup & 117 & Jelek \\
\hline
\end{tabular}

Dari tabel 7, diperoleh bahwa untuk indicator 1-3 tentang sikap siswa terhadap pelajaran matematika, kedua kelas memiliki interpretasi yang sama yaitu cukup baik. Berbeda pada indikator 4-6 tentang sikap siswa terhadap penerapan pendekatan pembelajaran pada masing-masing kelas, kelas CTL memperoleh 2 interpretasi baik dan 1 interpretasi cukup baik, sedangkan kelas RME memperoleh 1 interpretasi baik dan 2 interpretasi cukup baik. Sementara itu, pada indikator 7-8 tentang sikap siswa terhadap soal kemampuan koneksi matematis menghasilkan interpretasi yang berbeda pula pada kedua kelas. Kelas CTL memperoleh 1 interpretasi baik dan 2 interpretasi cukup baik, sedangkan kelas RME memperoleh 1 interpretasi baik, 1 interpretasi cukup baik dan 1 interpretasi jelek.

Selama pelaksanaan pembelajaran, peneliti menemukan beberapa data penting, penerapan pembelajaran melalui pendekatan Contextual Teaching and Learning bagi siswa kelas VII-D di SMPN 2 cilawu merupakan pembelajaran dengan pendekatan yang baru (Gambar 2). Hal tersebut terlihat dari aktivitas mereka saat pembelajaran berlangsung, tidak terbiasa dengan media kontekstual.

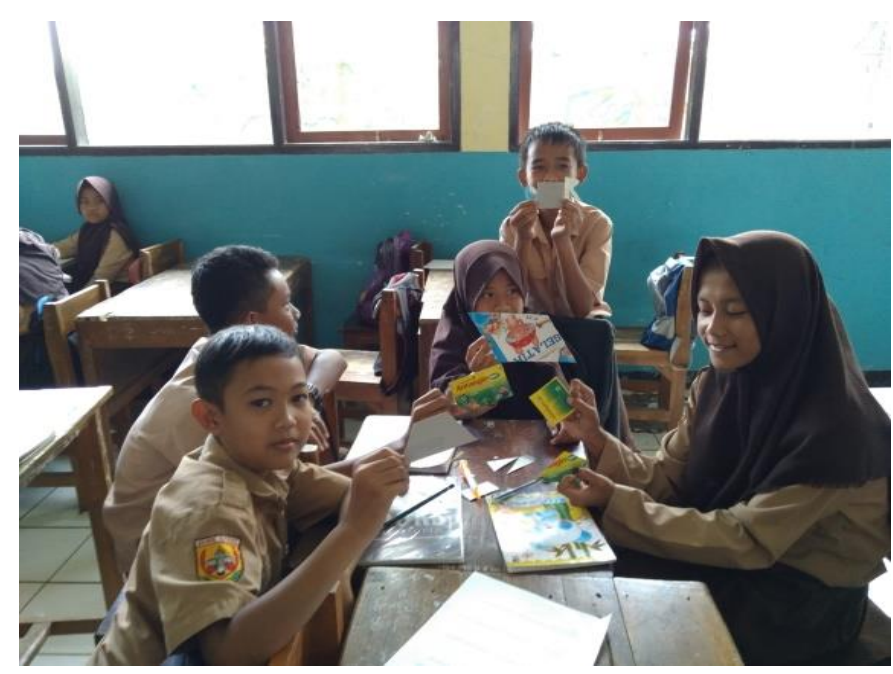

Gambar 2. Aktivitas Pembelajaran Menggunakan CTL

Di kelas lainnya, terjadi hal yang hamper mirip, karena penerapan pembelajaran melalui pendekatan Realistic Mathematic Education bagi siswa kelas VII-A di SMPN 2 Cilawu pun merupakan pembelajaran dengan pendekatan yang baru (Gambar 3). Tidak terbiasa dengan persoalan Matematika yang berhubungan dengan kehidupan sehari-hari. 


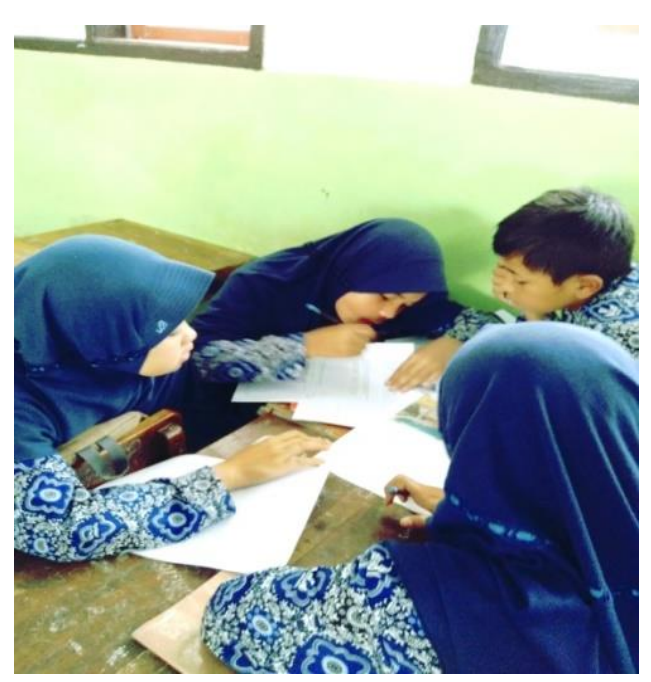

Gambar 3. Aktivitas Pembelajaran Menggunakan RME

Sementara itu, peneliti memiliki pendapat pribadi terhadap kedua pendekatan pembelajaran ini. Peneliti berpedoman pada apa yang telah terjadi dari awal sampai akhir penelitian. Masing-masing pendekatan pembelajaran memiliki kelebihan dan kekurangan, yaitu:

(1) Kelebihan CTL: a) penggunaan konteks membuat siswa menjadi lebih aktif dalam pembelajaran; b) siswa yang biasanya tidak menyukai pembelajaran Matematika dan lebih memilih mengobrol atau menggambar, bila disajikan dengan adanya konteks dalam pembelajaran, siswa tersebut menjadi ikut serta dalam pembelajaran; c) siswa yang tidak menyukai belajar berkelompok, menjadi bersemangat belajar berkelompok; dan d) siswa menjadi lebih mandiri dalam membuat catatan dikarenakan siswa tersebut bisa menyimpulkan dan menemukan konsep sendiri selama proses pembelajaran.

(2) Kekurangan CTL: a) karena kemampuan yang digunakan adalah kemampuan koneksi matematis, peneliti kesulitan dalam mencari soal soal yang berhubungan dengan CTL; b) Siswa yang tidak memperhatikan tidak dapat mengikuti dan menemukan konsep dikarenakan pendekatan CTL dapat menemukan konsep apabila sesuai dengan langkahlangkah; dan c) soal-soal koneksi matematis siswa yang dihubungkan dengan pendekatan CTL membuat siswa merasa bingung.

(3) Kelebihan RME: a) siswa lebih aktif dan mandiri dalam mencari konsep pembelajaran, karena siswa membayangkan dan mengkoneksikan sendiri ke dalam dunia nyata; dan b) siswa yang biasanya tidak mau diam, dan lebih memilih mengobrol dengan temannya menjadi lebih bersemangat saat pembelajaran menggunakan pendekatan RME, karena siswa tidak dibatasi dan tidak harus sama dengan orang lain dalam menemukan konsep, sehingga siswa menjadi lebih kreatif.

(4) Kekurangan RME: a) karena diawal pembelajaran siswa tidak diberikan sedikitpun materi, guru sulit mengkondisikan siswa yang bertanya mengenai LKS yang diberikan; b) karena siswa tidak diberikan benda nyata, dan siswa hanya diberikan gambar yang tampak nyata, banyak siswa yang merasa kesulitan dalam menyelesaikan LKS; dan c) guru kesulitan dalam menyesuaikan materi dengan pendekatan yang digunakan, dikarenakan tidak semua materi bisa dikaitkan dan dibayangkan oleh siswa sesuai dengan apa yang dibayangkan oleh guru.

Berdasarkan pembahasan diatas dapat ditarik kesimpulan bahwa perbandingan peningkatan antara CTL dan RME tidak terlalu signifikan, apabila dilihat dari hipotesis bahwa kemampuan koneksi matematis siswa yang mendapatkan CTL lebih baik daripada siswa yang mendapatkan pendekatan RME, ternyata tidak sesuai dengan hasil perhitungan pada uji $t$ yang menunjukan bahwa Ho diterima, sehingga kemampuan koneksi matematis siswa yang mendapakan CTL tidak lebih baik 
daripada siswa yang mendapatkan pendekatan RME. Tetapi dilihat secara analisis dari beberapa aspek seperti berikut:

Tabel 8. Hasil Perbandingan Kelas CTL dan Kelas RME.

\begin{tabular}{|ccc|}
\hline Keterangan & Kelas CTL & Kelas RME \\
\hline Rata-Rata Pretest & $29,71 \%$ & $19,04 \%$ \\
\hline Simpangan baku & 5,33 & 3,44 \\
\hline Rata-Rata Gain & 0,558 & 0,431 \\
\hline Simpangan baku Gain & 0,311 & 0,314 \\
\hline Skor Ideal $\mathbf{= 2 8}$ & &
\end{tabular}

Berdasarkan tabel 8, rata-rata pretest kelas CTL memiliki rata-rata pretest $29,71 \%$ lebih besar dari kelas RME yang memiliki rata-rata pretest $19.04 \%$, nilai rata-rata pretest menunjukan bahwa siswa kelas CTL lebih baik dari siswa kelas RME, hanya saja perbedaannya tidak signifikan. Simpangan baku kelas CTL memiliki simpangan baku 5,33\% lebih besar dari kelas RME yang memiliki simpangan baku 3.44\% , simpangan baku menunjukan bahwa ragam kemampuan siswa kelas CTL lebih beragam dibandingkan kelas RME. Rata-rata Gain kelas CTL memiliki rata-rata gain 0,554 lebih besar dari kelas RME yang memiliki rata-rata gain 0,431 dan simpangan baku gain kelas CTL memiliki simpangan baku gain 0,311 dan kelas RME yang memiliki simpangan baku 0,314. Dilihat dari nilai rata-rata gain yang sudah melibatkan pretest dan posttest hasilnya menunjukan kelas CTL lebih baik dari kelas RME hanya saja simpangan baku untuk ragam peningkatan kemampuannya cenderung sama atau merata.

Dari data di atas dapat kita simpulkan bahwa hasil penelitian yang telah dilakukan tidak sesuai dengan hipotesis awal, dimana pada hipotesis awal yang diharapkan bahwa pendekatan CTL lebih baik dari pendekatan RME. Hal tersebut dikarenakan data yang peneliti peroleh tidak cukup untuk membuktikan asumsi peneliti bahwa pendekatan CTL lebih baik dari pendekatan RME, sehingga kesimpulan akhir dari penelitian ini adalah pendekatan CTL dan pendekatan RME sama baiknya dalam meningkatkan kemampuan koneksi matematis siswa.

\section{Penutup}

Berdasarkan hasil penelitian dan pembahasan secara keseluruhan, sehingga dapat ditarik kesimpulan sebagai berikut: 1) Peningkatan kemampuan koneksi matematis siswa yang mendapat pendekatan CTL memiliki rata rata yang sedang; 2) Peningkatan kemampuan koneksi matematis siswa yang mendapat pendekatan RME memiliki rata-rata yang sedang; 3) Pembelajaran dengan menggunakan pendekatan CTL memiliki interpretasi sikap baik; 4) Pembelajaran dengan menggunakan pendekatan RME memiliki interpretasi sikap cukup baik.

\section{Referensi}

[1] Budiarto, A. (2012). "Penerapan Strategi Pembelajaran Contextual Teaching and Learning (CTL) Untuk Meningkatkan Keaktifan dan Hasil Belajar Siswa Kelas Xi Jurusan Teknik Kendaraan Ringan Pada Mata Pelajaran Sistem Pengapian Di Smk Muhammadiyah 1 Bantul". [online]. Tersedia: http://eprints.uny.ac.id/20174/1/Naskah\%20Skripsi\%20Andi\%20Budiarto\%2008504244012.pdf Desember 2016]

[2] Rahayu, D. V. (2009). "Perbandingan Kemampuan Koneksi Matematis Siswa Antara Yang Menggunakan Model Pembelajaran Advance Organizer Dengan Pembelajaran Konvensional”. Skripsi: STKIP Garut: Tidak diterbitkan. 
[3] Putri, R. I., \& Santosa, R. H. (2015). "Keefektifan Strategi React Ditinjau Dari Prestasi Belajar, Kemampuan Penyelesaian Masalah, Koneksi Matematis, Self Effecacy”. Jurnal Riset Pendidikan Matematika Volume 2 - Nomor 2, November 2015, (262 - 272). [online]. Tersedia: http://journal.uny.ac.id/index.php/jrpm/index [26 November 2016].

[4] Alwasilah, A. C. (2006). "Contextual Teaching and Learning CTL Menjadikan Kediatan Belajar Mengajar Mengasyikan Dan Bermakna”. Bandung: Kaifa Learning.

[5] Rahayu, D. V. (2009). "Meningkatkan kemampuan pemecahan masalah dan koneksi matematis siswa melalui pembelajaran kontekstual”. Tesis: UNPAS Bandung: Tidak diterbitkan.

[6] Nurmayanti, E. (2014). Perbandingan Kemampuan Koneksi Matematis Antara Siswa Yang Mendapatkan Model Pembelajaran Contextual Teaching and Learning (CTL) dengan pembelajaran langsung (Direct Learning). Skripsi: STKIP Garut: tidak diterbitkan.

[7] Maryati, I. (2017). Peningkatan Kemampuan Penalaran Statistis Siswa Sekolah Menengah Pertama melalui Pembelajaran Kontekstual. Mosharafa: Jurnal Pendidikan Matematika, 6 (1), 129-140.

[8] Afriansyah, E. A. (2017). "Desain Lintasan Pembelajaran Pecahan melalui Pendekatan Realistic Mathematics Education”. Mosharafa: Jurnal Pendidikan Matematika, 6 (3), 463-474.

[9] Wijaya, A. (2012). "Pendidikan Matematik Realistik Suatu Pendekatan Pembelajaran Matematika”. Bandung: Graha Ilmu.

[10] Afriansyah, E. A. (2012). "Implementasi PMRI dalam Materi Sifat Komutatif dan Asosiatif pada Bilangan Bulat untuk Level Siswa SD/MI”. Mosharafa: Jurnal Pendidikan Matematika, 1 (1), 19-25.

[11] Hidayat, R., \& Iksan, Z. H. (2015). "The Effect of RME On Students' conceptual Understanding of Linear Programming". Creative Education, 6, 2438-2445. [online]. Tersedia: http://file.scirp.org/pdf/CE_2015123013333885.pdf [23 November 2016]

[12] Afriansyah, E. A. (2016). "Investigasi Kemampuan Problem Solving dan Problem Posing Matematis Mahasiswa via Pendekatan Realistic". Mosharafa: Jurnal Pendidikan Matematika, 5 (3), 269-280.

[13] Afriansyah, E. A. (2016). "Makna Realistic dalam RME dan PMRI”. Jurnal LEMMA, Vol II No. 2, 96104.

[14] Alamiah, U. S. \& Afriansyah, E. A. (2017). "Perbandingan Kemampuan Komunikasi Matematis Siswa antara yang Mendapatkan Model Pembelajaran Problem Based Learning dengan Pendekatan RME dan Open-Ended”. Mosharafa: Jurnal Pendidikan Matematika, 6 (2), 207-216.

[15] Usdiyana, D., Purniati, T., Yulianti, K., Harningsih, E. (2015). Meningkatkan Kemampuan Berpikir Logis Siswa SMP Melalui Pembelajaran Matematika Realistik. Jurnal Pengajaran Mipa, Vol. 13 No. 1 April 2009. [online]. Tersedia: http://journal.fpmipa.upi.edu/index.php/jpmipa/article/view/300/211 [12 maret 2017]

[16] Risky, T. M. (2010). Keefektifan Model Pembelajaran Realistic Mathematics Education (Rme) Terhadap Hasil Belajar Peserta Didik Smk Negeri 6 Semarang Pada Materi Pokok Sistem.[online]. Tersedia: http://lib.unnes.ac.id/534/1/6698.pdf [11 maret 2017]

[17] Muhtadi, D. \& Sukirwan, S. (2017). Implementasi Pendidikan Matematika Realistik (PMR) untuk Meningkatkan Kemampuan Berpikir Kreatif Matematik dan Kemandirian Belajar Peserta Didik. Mosharafa: Jurnal Pendidikan Matematika, 6 (1), 1-12.

[18] Lestari, L. N. (2015). Upaya Meningkatkan Kemampuan Komunikasi Matematis Siswa dengan menggunakan Pendekatan Realistic Mathematics Education (RME) dalam Pembelajaran Matematika. Skripsi: STKIP Garut: tidak diterbitkan.

[19] Alamiah, U. S. \& Afriansyah, E. A. (2017). Perbandingan Kemampuan Komunikasi Matematis Siswa antara yang Mendapatkan Model Pembelajaran Problem Based Learning dengan Pendekatan RME dan Open-Ended. Mosharafa: Jurnal Pendidikan Matematika, 6 (2), 207-216.

[20] Herdiana, H., \& Sumarmo U. (2014). "Penilaian Pembelajaran Matematika”. Cimahi: PT Refika Aditama.

[21] Rusman (2012). “Model-Model Pembelajaran Mengembangkan Profesionalisme Guru Edisi Kedua”. Bandung: PT Raja Grafindo Persada.

[22] Murdiani, H. (2014). “Desain Penelitian Eksperimen”. [online]. Tersedia: http://hirpanmurdani.blogspot.co.id/2014_05_01_archive.html?m=1 [29 Desember 2016] 
[23] Nur'aini, I. L., Harahap, E., Badruzzaman, F.H., Darmawan, D. (2017). Pembelajaran Matematika Geometri Secara Realistis Dengan GeoGebra. Matematika: Jurnal Teori dan Terapan Matematika. Vol. 16 No. 2 Desember 2017. pp. 73-78. 